\title{
THINKPIECE: MAKING A CASE FOR NURTURING PASIFIKA STUDENTS THROUGH THE ARTS IN NEW ZEALAND: NOW WOULD BE A GOOD TIME
}

FRANCES EDWARDS

Te Kura Toi Tangata Faculty of Education

The University of Waikato

\author{
PADMA KRISHNAN \\ Southern Cross Campus \\ Auckland
}

This think piece was inspired by observations of students in a school with more than 80 percent Pasifika students and less than 1 percent European students, and in whose community the vibrancy of the Pacific cultures is evident.

The academic progress of Pasifika students in New Zealand schools has been identified as a real concern for many years (Education Review Office, 2012) yet progress in addressing the documented achievement gap has been slow. We know there is no 'silver bullet' to resolve the challenges, so instead we must look to a range of strategies that together will make a difference for Pasifika learners. The recent change in New Zealand classroom and school design, with the introduction of flexible Innovative Learning Environments (ILEs), provides school leaders and teachers with new possibilities for pedagogy and curriculum design. These new possibilities could include reconceptualising the place of the Arts (i.e. students' cultural customary and contemporary arts) in the school curriculum, as we believe that placing the Arts more centrally in the curriculum experienced by Pasifika students may contribute to better learning outcomes for this priority group.

The Arts are an essential part of any society, civilisation, and culture. They present in a variety of ways to record feeling and insight, and provoke avenues for creativity and expression. The Arts have been defined in the past as "the practice of creating perceptible forms expressive of human feeling" (Langer, 1966, p. 6), and this definition still resonates today even though the range of media has extended over time. Through engagement with the Arts people are challenged to develop through and beyond language. Not surprisingly then, involvement with the arts has been shown to be linked student academic achievement (Eisner, 1998, Gullat, 2007).

Students classified under the Pasifika banner come from a wide range of cultures and backgrounds; some are third or fourth generation, New Zealand-born and integrated into New Zealand culture, whereas some have very recently arrived in New Zealand from their Pacific homelands and are fluent in all aspects of their home language and cultural practices. Pasifika students as a whole are not doing as well as they should be in the New Zealand education system, with New Zealand agencies listing them as "at risk" (Education Review Office, 2012). To address this in part the Pacific Education Plan (PEP) and Implementation Plan 2013--2017 (Ministry of Education, 2013) was developed as a strategic document with the aim of raising Pasifika learners' participation, engagement and achievement in education. The vision of PEP is:

Five out of five Pasifika learners participating, engaging and achieving in education, secure in their identities, languages and cultures and contributing fully to Aotearoa New Zealand's social, cultural and economic wellbeing. (Ministry of Education, 2013)

Bearing this in mind, we turn our attention to Pasifika students in New Zealand schools, and in particular, we will focus on schools in which Pasifika students are the large majority of the school population. In a literature review that focussed on the classroom experiences of Pasifika students, it 
was found that many teachers demonstrate a strong commitment to the educational achievement of Pasifika learners through enabling pedagogical practices (Ferguson, Gorinski, Wendt Samu, \& Mara, 2008). Our anecdotal evidence would concur with this and suggest that teachers in these schools are well aware of their responsibility to lift student achievement. Unfortunately, though this often results in a narrow curriculum with extra focus on literacy and numeracy. In such schools, the cultural and contemporary Arts are not always promoted, except for preparation to participate in events such as Polyfest. We argue that paying closer attention to the Arts within a balanced curriculum would be a way for schools to be culturally responsive and thus accelerate Pasifika student achievement. Given the central place of the arts in Pasifika cultures it seems logical that they be placed more centrally in schools. Bourdieu \& Passerson (1977) highlight the fact that students whose values and culture align with that of the school achieve better than those students who differ in these two areas. Hence, the cultural capital of students does play an important role. According to the likes of Fletcher, Parkhill, Fa'afoi, and Taleni, (2006) and Siope (2011) the notion of Pasifika cultural capital helps us understand that the way students perform academically is related to the social and cultural resources of the home and the community in general, as well as the school community.

A number of New Zealand studies illustrate the potential benefits of a focus on the arts for Pasifika students. Here are some examples. In their case study of a preschool Pasifika boy with a penchant for drumming, Cooper and Hedges (2014) found that success in this activity contributed towards the boy's growth in confidence, as well as his identity as a boy of Pacific descent. His ECE teachers recognised the funds of knowledge the boy brought to the Centre and offered a fluid and flexible curriculum to enable him to develop his drumming skills and teach other children around him. This meant he was able to "[develop] a positive identity as a competent and capable learner whose funds of knowledge and musical competence were recognised, honoured and respected by multiple others" (p. 172). This case study illustrated the importance of engaging in reciprocal relationships, and enhancing collaboration to benefit children's growing learner and cultural identities.

In a secondary school setting, Coleman (2011) investigated whether using process drama would engage Year 10 Pasifika boys from an Auckland school, and found that students' low expectations were raised as a result of their participation in process drama. Coleman (2011) found that using process drama required physical, active, group oriented and student centred learning more closely resembling students' home cultures. He argued that "teachers incorporate more authentic, student-led activities that will engage students more fully with their lessons" (p. 29), thus reducing cultural barriers to learning. In a larger study involving Pasifika students from three secondary schools who contributed to a joint arts performance called Malaga, Mackley-Crump (2011) reported on students finding strengthened identities, growth in confidence and motivation through their involvement in the many hours of preparation and rehearsal, and then the multiple performances. The style of learning that was facilitated during the Malaga "could be termed a more Pacific approach, reflective of the church and community-based environments through which much of the cast develop their musical abilities" (Mackley-Crump, 2011, p. 263). Similar sentiments about a 'Pacific approach' were evident at the conclusion of a study into the development of literacy for Pasifika students by Parkhill, Fletcher and Fa'afoi (2005). This research found that when Pasifika values, language identities and cultural knowledge were woven into the teaching and learning practices, learning was more likely to be enhanced.

Because of the nature of the arts, Pasifika students' involvement in the arts provides them with opportunities to work actively and collaboratively with peers and often results of activities are group focussed rather than individually focused, which fits with most Pacific cultural norms (Tiatia, 1998). Most Pasifika cultures place high value on dance, singing and other music, drama, group performances, visual art, sculpture/carving and so on. When teachers allow for the students' use of cultural capital in arts-based activities it provides them opportunity for expression of cultural identity, personal strengths and contribution of student voice as well as production of knowledge. This also means the links between home and school are strengthened. The success of such group-based activities may initiate a self-examination of pedagogies for teachers working with Pasifika students.

The pedagogies being used in New Zealand classrooms are changing rapidly at present, particularly with the development of innovative learning environments (ILE). This time of change provides further opportunities to reconsider how curriculum is prioritised and how it is experienced by students. The physical spaces offered by ILEs can be a nurturing factor if pedagogy and cultural content 
knowledge, skills and understandings are embraced. It has been argued that when schools transition to an ILE, engagement with the school stakeholders is a key to success (Bishop, O'Sullivan \& Berryman, 2010; Wall, 2014). This consultation could include asking stakeholders how the school environment could best be used for learning. Pasifika students will be nurtured when "there is a fundamental change in thinking and practice in schools, from a mono-cultural to a multicultural lens, in order to promote effective parent community-school engagement in Pasifika contexts" (Milne, 2009). The physical school environment in an ILE provides larger spaces that are more flexible, and therefore inclusion of the arts as a more central part of curriculum is not as physically constrained as it was. This is seen as a benefit to priority learners in New Zealand.

In summary then, we are calling for closer examination of the place of the Arts in New Zealand schools, for the benefit of Pasifika students, and all students. Moving the focus to using the Arts more centrally in curriculum is culturally responsive when Pasifika students can draw on their own cultural norms and knowledge. We acknowledge that expressions of the Arts exist in communities from which these students come, and they have engagement with the cultural customary and contemporary arts in their cultural communities outside of school. However we believe it is an opportune time to consider bringing this engagement more centrally into schools as part of moves to ILEs because these environments are able to accommodate Arts education, and arts based learning in what are called 'core' subjects, more easily. Given the need to improve outcomes for all of our student population, nurturing the Arts and learning through the arts for Pasifika students will help build self-esteem motivation and engagement in learning. As school leaders and Boards of Trustees continue ILE planning and implementation activities and teachers reconsider pedagogy in response to this opportunity, now is a good time to be talking about this.

\section{References}

Bishop, R., O’Sullivan, D., \& Berryman, M. (2010). Scaling up education reform: Addressing the politics of disparity. Wellington, New Zealand: NZCER Press.

Bourdieu, P., \& Passerson, J. (1997). Reproduction in education, society and culture. The School Review, 86(1), 144-147.

Coleman, C. (2011). "You can try sound brainy": The use of process drama to engage Pasifika boys. Set: Research Information for Teachers, 1, 23-30.

Cooper, M., \& Hedges, H. (2014). Beyond participation: What we learned from Hunter about collaboration with Pasifika children and families. Contemporary Issues in Early Childhood, 15(2), 165-175. doi:10.2304/ciec.2014.15.2.165

Education Review Office. (2012). Improving education outcomes for Pacific learners. Wellington: New Zealand: Education Counts. Retrieved from https://www.educationcounts.govt.nz/statistics/schooling/nationalstandards/National_Standards

Eisner, E. W. (1998). Does experience in the arts boost academic achievement? Journal of Art and Design Education 17(1), 51-60. doi:10.1111/1468-5949.00105

Fletcher, J., Parkhill, F., Fa'afoi, A., \& Taleni, L. T. (2006). Pasifika students' perceptions of barriers and support to reading and writing achievement in New Zealand schools. New Zealand Journal of Educational Studies, 41(2), 163-182.

Ferguson, P. B., Gorinski, R., Wendt Samu, T., \& Mara, D. (2008). Literature review on the experiences of Pasifika leaners in the classroom. Retrieved from http://www.educationcounts.govt.nz/publications/pasifika/27772/27574

Gullatt, D. E., (2007). Research links the arts with student academic gains. The Educational Forum, 71(3), 211-220. doi:10.1080/00131720709335006

Langer, S. K. (1966). The cultural importance of the arts. Journal of Aesthetic Education, 1(1), 5-12.

Mackley-Crump, J., (2011). Malaga - The journey: Performing arts as a motivational tool for Pasifika students in Aotearoa New Zealand. The Asia Pacific Journal of Anthropology, 12(3), 255-273. doi:10.1080/14442213.2011.566573

Milne, B. A. (2009). Colouring the white spaces. Cultural identity and learning in school (Doctoral Thesis). University of Waikato, Hamilton, New Zealand. Retrieved from http://researchcommons.waikato.ac.nz/handle/10289/7868 
Ministry of Education. (2013). Pasifika Education plan 2013-2017. Retrieved from http://www.minedu.govt.nz/NZEducation/Educationpolocies/PasifikaEducation/media/MinEdu/Files/EducationSectors/PasifikaEducation/PEPfoldup12Fe

Parkhill, F., Fletcher, J., \& Fa' afoi, A. (2005). What makes for success? Current literacy practices and the impact of family and community on Pasifika children's literacy learning. New Zealand Journal of Educational Studies, 40(1-2), 61-84.

Siope, S. A. M. (2010). Children of the migrant dreamers: Comparing the experiences of Pasifika students in two secondary schools attempting to be culturally responsive to mine from a generation ago (Masters thesis). University of Waikato, Hamilton, New Zealand. Retrieved from http://researchcommons.waikato.ac.nz/handle/10289/5003

Tiatia, J. (1998). Caught between cultures. A New Zealand-born Pacific Island perspective. Auckland, New Zealand: Christian Research Association.

Wall, G. (2014). Māui whakakau, kura whakakau-Modern learning environments to support priority learners. Wellington, New Zealand: Ministry of Education. Retrieved from http://www.education.govt.nz/assets/Documents/Primary-Secondary/Property/School-propertydesign/Flexible-learning-spaces/Maui-Whakakau-TLE-factsheet.pdf 